\title{
Italianness, Catholicism and Womanhood in the American Success Story of Mother Frances Cabrini, The Patron Saint of Immigrants
}

Frances Xavier Cabrini (1850-1917) was a Catholic nun of Italian origin, one of the first women missionaries who decided to leave for the United States in order to offer assistance to Italian Americans at the peak of their mass scale migration (1889-1917). Following an unprecedented success of her Missionary Institute of the Sacred Heart, she obtained American citizenship and was proclaimed the first U.S. Catholic saint in history, a global patron of immigrants. Until quite recently her work had been studied almost exclusively within a purely ecclesiastical context. However, nowadays her crucial intercultural experience is being revised by U.S. gender scholars who perceive her as a strong and independent woman of her time, founding and running a charity enterprise on three continents, little short of a Catholic feminist avant la lettre, but also an education innovator, pioneer of bilingual schooling as well as of an inclusive model of integrating immigrants into a modern society.

Keywords: immigration, Italian American, Frances Cabrini, Catholic, gender

\section{Introduction}

Even today the Italian American community claims its immigrant experience to be uniquely tragic and mythologized (Tucci 2015). To millions of Italian immigrants to the United States, contemptuously labelled as wops or dagos, America hardly seemed 'the land of the free'. While ethnic prejudice, economic exploitation

${ }^{1}$ Contact: p.podemski@uw.edu.pl of Mother Frances Cabrini, the Patron Saint of Immigrants, Studia Migracyjne - Przeglad Polonijny, 4 (170), p. 137-156. 
and acts of physical violence compelled many to give up their American dream whatsoever, the ones who did not ultimately choose to return to Italy embarked on a troubled path toward acquiring the status of 'white', i.e. mainstream Americans.

Apart from what was perceived as their inferior 'racial' background (North and South Italians were actually regarded as two distinct human 'races'), it was also the Catholic faith of the Italians that made them, alongside the Irish and Polish newcomers, a foreign body within the WASP-dominated society of Gilded Age America. Deemed simply "un-American", Catholicism was long associated with illiteracy and thus ignorance, poverty and crime as well as blind obedience to a foreign, Rome-based hierarchy (McGreevy 2003: 11).

Arriving at New York's Battery Park terminal Frances Xavier Cabrini (1850-1917), an Italian Catholic nun from the provincial diocese of Lodi seemed nothing less than a perfect incarnation of the Italian American stereotype. Unable to speak a word of English, utterly devoted to Pope Leo XIII who had personally commanded her to dedicate her life to the American mission, a deeply conservative and proud Italian patriot highly critical of the U.S. political and social model, arguably Mother Cabrini was yet to undergo a remarkable transformation in terms of her national, religious and gender identity. The importance of her experience, however, is not confined to the personal aspect of how 'the land of opportunity' made a submissive Italian woman's life into an American success story. It is also about the more general Italian American fate that she epitomized and largely contributed to improve, alongside such far more prominent and widely known men of her time as Generoso Pope or Fiorello La Guardia (Podemski 2016).

The aim of this paper is to set the case of Frances Cabrini into a broader context of contemporary immigration studies through an analysis of how the immigrant experience impacted the three fundamental dimensions of her identity: ethnicity (i.e. her Italianness), religion (i.e. her Catholicism) and gender (i.e. her womanhood). Thus the research questions include the following:

1) How far is it true to say that the impressive expansion of Mother Cabrini's foundations throughout the United States and beyond resulted from her adopting an American-inspired business approach?

2) To what extent and in what ways was Mother Cabrini led to question the beliefs regarding the nature of Catholicism and womanhood she had been brought up with back in Italy?

3) What was the significance of Mother Cabrini's actions in reference to the gradually improving social status of the Italian community in the United States?

As far as the research methods are concerned, the author's intention is to remain loyal to his natural field of historical and intercultural studies. The historical method will be applied in order to determine some solid facts of the future saint's 
life and work, such as specific places, dates and activities. In few cases, only where appropriate, e.g. when discussing the success and growth of the Cabrini-founded institutions and the numbers of people involved and affected, hard statistical data will be cited. However, in many other instances, while dealing with matters as subtle and intangible as one's identity in transition, qualitative analysis will be based on a comparative study of written primary sources reflecting Cabrini's changing self-perception e.g. her own abundant correspondence or eye-witness testimonies left by her close companions. From an intercultural standpoint Mother Cabrini's multiple identities, continuously (re-)constructed around the notions of ethnicity, religion and gender will be looked upon, also in the light of how these notions were perceived by distinct cultural groups (Italian, Italian American, mainstream American). To put it bluntly, one needs to find out what it meant to be an Italian, a Catholic and a woman in the cultural context of Italy proper, an Italian American 'ghetto' and WASP American society at the turn of the $20^{\text {th }}$ century (Piller 2011: 8).

Finally, still in line with the intercultural approach, crucial findings stemming from monographies devoted to her work, reflecting both the Italian and the American perspective, will be considered for contrast and depth. Obvious as it may seem, one needs to point out that for many decades the experience of Frances Cabrini had been deemed precious and interesting almost exclusively within the Catholic circles, providing us with some precious primary sources. Volumes devoted to her numerous travels were published almost immediately after her death, containing collections of her original letters (Serpentelli 1925; Cipolla 2012 [1926]). They were followed by a detailed Italian language primary account of her life, authored by a long-time collaborator, travel companion and private secretary, Sister Saverio De Maria (De Maria 1927). Two more biographies in Italian were released in 1938, the year Mother Cabrini was beatified by Pope Pius XI (Vian 1938, De Sanctis Rosmini 1938). Her canonization by Pius XII in 1946 put an end to this first wave of purely denominational and hagiographical interest in her life and deeds, also because of the changing political context. Throughout the interwar years Cabrini's exploits in the United States had been cherished with equal enthusiasm by the Vatican and the Mussolini regime, therefore after WWII it was probable her story would be perceived exclusively as a leftover of the previous fascist propaganda of Italian success worldwide (D’Agostino 2004: 252).

Nevertheless, as some contemporary scholars - first and foremost Italian Americans - began to critically revisit the deeply embedded stereotype of the Italian immigrant in the United States (LaGumina 1999), the story of Frances Cabrini re-surfaced as an indispensable element of this panorama. Her name appeared in the Italian-American Encyclopaedia (LaGumina 2000) and became a part of the Catholic experience in America (D’Agostino 2004, Fisher 2008), interesting also to more prominent Irish American authors (McGreevy 2003, Cummings 2009). Simultaneously, a new wave of publications could be found, devoted 
specifically to the modern aspects of Cabrini's success story, picturing her in many ways as a woman ahead of her time, in terms of her model of education (Barbagallo 2013), charity (Scaraffia 2004) and immigrant integration policies (Sullivan 1992) as well as women's role in society (De Luca 2000). A revised version of the classic biography by Lucetta Scaraffia was published in 2017 to commemorate the hundredth anniversary of Mother Cabrini's death, with a foreword provided by Pope Francis (Scaraffia 2017). The author believes it is through combining both traits of Cabrini historiography as outlined above (hagiographic primary sources versus more recent critical studies) balanced conclusions can be reached. With this goal in mind the present paper has been built around the following three sections discussing: 1) Frances Cabrini's initial ideas shaped by her traditional Italian upbringing; 2) her American success story as reflected by the rapid expansion of her Missionary Institute of the Sacred Heart; 3) her identity dilemmas and choices in terms of her shifting ethnic allegiance, her views on the nature of Catholicism and her own role within the Church as a woman.

As one may already have noticed, pivotal to the present study are the categories of identity and ethnicity as well as gender and feminism. Identity is not meant exclusively as "...the awareness that an individual has of being a distinct, persisting entity..." (AHD), but - more to the point - “...the stable conception that a subject has of him - or herself as an individual...” or simply “...one's true self..." (Cashmore 2004: 95). A key aspect of Mother Cabrini's identity, or a prominent one among her multiple identities, is her Italian, then Italian American ethnicity, or a sense of belonging to "... a group of people sharing a common cultural or national heritage and often sharing a common language or religion...” (AHD). Although Glazer \& Moynihan (1975: 1) considered it still a new term, recent research by linguists has revealed its much older uses dating back to at least 1920 (AHD), a year not very distant from Frances Cabrini's own times. Even more so, as Thomas Hylland Eriksen (2010: 48) argues, in accordance with its ancient Greek roots ("heathen", "pagan"), the term ethnicity actually re-emerged in modern-day America as "... a polite term referring to Jews, Italians, Irish and other people considered inferior to the dominant group". It is not within the author's possibilities in the present paper to discuss the problem of dubious Italianness, or at least fragile national identity, of people called Italian Americans at that time. In her own writings, as we shall see, Mother Cabrini does acknowledge a lack of linguistic uniformity among the immigrants but nevertheless it never crosses her mind to question their common Italian ethnicity based - in full accordance with Max Weber's concept - on beliefs rather than facts as well as on an idea of religious brotherhood (Żelazny 2004: 28).

Apart from her evolving Italianness, it is also Frances Cabrini's womanhood that must be deemed highly relevant to her experience and her testimony. When discussing this dimension, the author understands gender as "...the behavioral, cultural, or psychological traits typically associated with one sex..." (MWD) or 
the ways the protagonist incessantly constructs her own image as a woman. It is a far more complex issue whether or not the author's usage of the term feminism can be judged proper in reference to a Catholic nun at the turn of the $20^{\text {th }}$ century. However, before one rejects such a thought it is useful to resort to the meaning of this word offered by the American Heritage Dictionary: “...belief in or advocacy of women's social, political, and economic rights, especially with regard to equality of the sexes..." (AHD). Similarly, when turning to more specialized sources, it needs to be emphasized that the term was actually used in the United States as early as 1910 and its core values are those most certainly represented by Francesca Cabrini like "... address[ing] unequal relations of power..." "...the drive for social justice..." or "...illuminat[ing] the patriarchical framework that generates and assigns traditional gender roles..." (Dhamoon 2016: 88). It is within this context that the author allows himself to consider Mother Cabrini a Catholic feminist, though most certainly, as stated more than once, only avant la lettre.

\section{The Origins: 'Not to the East, but to the West'}

First and foremost, Mother Cabrini's stunning success story was certainly made possible through a gradual rejection of her provincial Italian background in order to embrace the unthinkable opportunities offered by her new immigrant identity. Nothing indeed seemed to presage that the twelfth child (only four of her siblings would survive to their adult age) of the Cabrini family, the little and sickly Francesca, born on July 15, 1850 at Sant'Angelo Lodigiano, would one day conquer the New World (Scaraffia 2004: I). Considering her difficult living conditions and the psychological experience of suffering resulting from the deaths of numerous family members, she found it a natural choice to become a Catholic nun as many women of her low social status often did at the end of the $19^{\text {th }}$ century for a number of both spiritual and social reasons (McGreevy 2003: 129). Supervised by her rigid older sister, Rosa, Francesca led an intense spiritual life. Through the reading of Catholic press, the only accessible and valued source of information in her little world of the Italian provinces, the future saint developed an interest in the missionary dimension of the Catholic Church, and especially in the work of Saint Francis Xavier, the $16^{\text {th }}$ century Jesuit and apostle in the Far East. The girl thus chose a life objective - seemingly childish, romantic and hardly feasible - to follow in the footsteps of her beloved saint and travel to China as a missionary. However, for reasons we shall discuss further, at that time not a single female missionary religious order existed in all of Italy (Scaraffia 2017: 29).

Because of the lack of financial assets as well as her frail health, Francesca was rejected by two religious orders (the Daughters of the Sacred Heart of Jesus and the Canossian Daughters of Charity), which made her dream of becoming a nun seem 
utterly unrealistic (Scaraffia 2017: 38). In such circumstances, having completed her education at the Arluno college in 1868, the young woman decided to take an opportunity to start a career as an elementary school teacher (Barbagallo 2013: 11-12). She soon proved so successful in her roles as a teacher and a tutor, first at the Vidardo grammar school (1872-1874) and subsequently at the Home of the Providence (orphanage) at Codogno (1874-1880), that local Church authorities would make desperate attempts to keep her within the area as a precious human asset by dissuading her from persisting with her larger projects outside Lombardy (De Maria 1984: 39-42).

Nevertheless in 1880 Frances Xavier (the second name added to honor her beloved apostle of Asia) managed to realize the first of her dreams, establishing along with a few women of a similar social status - a new religious order: the Missionary Sisters of the Sacred Heart of Jesus. Many biographers have emphasized that - contrary to most similar cases at that time - the Cabrini Institute was not created at the request of a high-ranking prelate, but out of a personal initiative of a woman foundress. Nevertheless one might argue she did obtain the encouragement and indispensable approval of the bishop of Lodi, Domenico Gelmini, who hoped to entrust the new institution with a Catholic education of the youth in his diocese (De Maria 1984: 54). Thus on November 15, 1880 the first of Mother Cabrini's foundations was established - the Codogno college, attended by both the daughters of the local middle class families capable of making the necessary financial contributions and the non-paying poor orphans taken care of by the sisters (Scaraffia 2004: I).

The foundress never gave up the more far-reaching objectives of becoming a proper missionary. One reason why such projects seemed totally unrealistic was that while Catholic nuns had been sent to European colonies in their thousands to run schools and orphanages, their status can best be defined - as one scholar has put it - as "double invisibility" (Curtis 2016). With their role perceived as purely auxiliary, until the second half of the $19^{\text {th }}$ century, they had been denied the formal status of missionaries, reserved for male clergy (Cummings 2018: 13). However, a widely spread conviction repeated in sources close to the Cabrini congregation, according to which they were the second oldest female institute officially labeled as "missionaries" in the history of the entire Catholic Church (Scaraffia 2017: 53), remains an overstatement at best. One must bear in mind that apart from Adèle Euphrasie Barbier's Religieuses de Notre Dame des Missions, established in 1861 and approved by the pope no earlier than 1869, the French colonial empire witnessed an impressive expansion of similar communities, some of them a female branch with links to a male institution (e.g. Franciscan Missionaries of Mary, established in 1877), other ones - missionaries in all but name (Curtis 2010).

Nevertheless among the many obstacles Frances Cabrini needed to overcome there were actual objections from the Vatican hierarchy attempting to dissuade her 
from formally including the word "missionary" in the new institute's name (Sullivan 1992: 35-37). A rare opportunity to justify the missionary aspect of the Cabrini project was offered by Giovanni Battista Scalabrini, the bishop of Piacenza, preoccupied with the fate of Italian immigrants in North America (Barbagallo 2013: 13). The bishop thought it necessary to support the suffering Italians in keeping both their Catholic faith and their national identity through training and sending to the United States Italian priests ready to accompany their compatriots in their harsh experience of a new life in America (Sullivan 1992: 40). Bishop Scalabrini requested Mother Cabrini's assistance and in this endeavor she even obtained direct support from the pope during an audience she was granted on her visit to the Vatican in January 1889. "Not to the East, but to the West. Your China is the United States" Leo XIII is reported to have said (Scaraffia 2004: I). A few weeks later, on March 31, 1889, seven Italian missionary sisters, including the foundress, first set foot at Battery Park in New York City after their first, and yet not last, Atlantic crossing (De Maria 1984: 109).

\section{The Enterprise: 'I can do all things in him who strengtheneth me'}

As Frances Cabrini was approaching the shores of America, the Italian community in the United States was experiencing its darkest hour. The impressive charitable and educational enterprise launched by the Lombardy nun would turn out to be decisive in transforming the public image of Italian Americans. However, in order to succeed in this respect, she first needed to fight an uphill battle against racial, religious and gender prejudice.

Leo XIII's invitation for Mother Cabrini to embark on her American mission stemmed from the Roman Curia's growing awareness of the difficult conditions faced by Italian Catholics in the United States, until 1908 officially regarded as a missionary territory under the jurisdiction of the Vatican Congregation of the Propagation of the Faith, or Propaganda Fide (Gillis 1999: 48). The editor of "Il Progresso Italo-Americano", one of the spokesmen of the Italian-American community, in the very same year 1889 stated that Italians "....were hated, treated like animals, persecuted worse than blacks [... ], exploited both economically and morally by other Italians and Protestants..." (Sullivan 1992: 72). The first problem mentioned was often defined as "the padrone system" or even "Italian slave trade" e.g. exploitation of new immigrants by those compatriots who had arrived earlier and took advantage of their status. This reality was vividly described in a letter the Pope sent to American bishops in December 1888:

At the outset the emigrants' crossing itself is full of dangers and injuries; for many of them fall into the hands of avaricious men whose slaves, as it were, they become, 
and then herded in ships and inhumanly treated, they are gradually depraved in their nature. And when they have reached the desired land, being ignorant of both the language and the locale, and engrossed in their daily toil, they become the victims of the trickery of the dishonest or the powerful by whom they are employed. (Shaw 2016: 74)

Apart from their dishonest countrymen, Italians also fell prey to the general anti-Catholic prejudice of that time according to which U.S. Protestants regarded the Church of Rome as a feudal and reactionary institution, and thus "un-American", irreconcilable with the liberal and independent spirit of the American democracy (LaGumina 1999: 179). Nevertheless it needs to be pointed out that what prevailed among Italian Americans themselves was anticlericalism and the will to distance themselves from the Church regarded as guilty of the material and moral misery of their country of birth, which certainly did not make Mother Cabrini's mission easier (Sullivan 1992: 78).

Neither can one ignore the fact that even within the American Catholic community itself Italians were looked at with contempt and a visible superiority complex by their dominant brethren of Irish descent. Therefore, unable to maintain their own "national" parishes, Italian American Catholics were forced to pray in the basements of the church buildings run by Irish vicars and bishops (Cummings 2009: 6). Taking into consideration the magical, popular nature of the Catholic faith brought with them from the South of Italy, or - to quote Michael Corrigan, the archbishop of New York (1880-1902) - “...so great and profound ignorance of the most fundamental truths of our Religion that astonishes even our enemies..." (Scaraffia 2004: II), not only Protestants considered Italians "only formally" Christians, followers of a faith interpreted as superstition, hence “... primitive in every way..." “...unassimilable...” (LaGumina 1999: 113-118). The Report on Italian emigration prepared by the Vatican Congregation of Propaganda Fide in November 1887 defined Italians as “...the pariahs of the great American republic..." (Scaraffia 2017: 69).

Already from her direct experience, Mother Cabrini would later confirm this sad reality in a letter sent from Chicago to Rome on February 18, 1906:

Poor emigrants are so often cheated by those who pretend to be their protectors. [...] During my journey I saw these dear fellows of ours [...] separated for years from their families, far from the Church, deprived of the holy joys which in our own country the poor peasant has at least on Sundays. [...] Here the hardest labor is reserved for the Italian worker. There are few who regard him with a sympathetic eye, who care for him or remember that he has a heart and a soul [...]. How much real joy does he not give up in leaving his native country for foreign lands, without anyone to guide him on the road of true happiness, which does not consist in hoarding heaps of money, which, more often than not, cannot be enjoyed when misfortune comes. (Serpentelli 925: 270) 
The Cabrini missionaries were soon to experience the scale of the conflict within the New York Catholic community. As soon as they arrived, they were reportedly told by Archbishop Corrigan: "You must go back [to Europe] aboard the same steamer that brought you here." (Scaraffia 2018: 81). In order to defend their mission the nuns felt compelled to cite the Pope's personal order for them to travel "to the West" (Sullivan 1992: 79). Apart from the abovementioned Irish diffidence towards Italians as such, the nuns would soon realize the existence of yet another dividing line: separating progressive Catholics, defined "Americanists", often of Irish descent, from conservatives - usually German and Italian - loyal to the intransigent doctrine of the Holy See (Cummings 2009: 7). Cabrini would always propagate the idea that "Rome is our spiritual center, the District of Columbia for Christianity...", accusing many Italian priests of being "... attached to the [Italian] tri-color flag rather than to the Pope." (D’Agostino 2004: 58) Therefore, the arrival of an ambitious nun unconditionally faithful to the Roman Curia, openly critical of the liberal Italian state, widely believed to have been sent by the Propaganda Fide in an attempt to strengthen the traditionalist wing, could easily twist the local balance of power.

What one might find surprising, though, even paradoxical, was yet another obstacle that materialized on Mother Cabrini's path at the very beginning of her American experience, an obstacle that could be interpreted from a feminist standpoint. Having directly experienced the new missionaries' desire for active involvement in social affairs and their own freedom of action, even the Italian priests who had been sent to New York by Bishop Scalabrini, also one of the drivers behind the Cabrini mission, sought to convince the nuns to go back to Italy (Sullivan 1992: 81). Adding their objections to those of the archbishop, Scalabrini's priests made it clear they had requested assistance from "...obedient nuns, ones that [would] execute orders given to them, not ones that [would] launch their own initiatives or pursue their own agenda..." (Scaraffia 2004: II). Since both Corrigan and the Scalabrini priests had denied them any financial assistance or accommodation, Mother Cabrini's decision not to return to Italy meant the nuns needed to rely exclusively on themselves, i.e. to beg on the streets. In such an absurd and tragic way came true the wish previously revealed by some of the nuns to be able to find in America more space to freely express themselves as independent women, in the capacity of Catholic nuns (Sullivan 1992: 61).

However, on the other hand, as one of the biographers has observed, the difficult encounter with the realities of the United States made the experience of Mother Cabrini more authentic and closer to the actual fate of Italian immigrants whom she had chosen to sustain in their hardship:

Apart from her personal qualities, it was also the very fact she had been rejected by the high hierarchy, thus weakened and freer at the same time, that enabled Cabrini to find her own new way into the American society. This clash with the American reality, 
with hardly any institutional shield or funds, was very similar to what the emigrants were going through, and this experience proved valuable for her in developing strategies of assistance to them. (Scaraffia 2004: III)

Catholic scholars emphasize how in those dramatic circumstances it was exclusively the solid and genuine religious faith of the future saint that enabled her to continue her mission, according to the motto of Apostle Paul she would take up during her next journey from Genoa to New York on September 6, 1894: "Omnia possum in eo qui me confortat", Latin for "I can do all things in him who strengtheneth me." (Cipolla 2012:154)

An utterly fundamental problem facing the Catholic community in America was the need to provide a sound Catholic education to their children (Cummings 2009: 9). In the case of Italians, it was also the problem of taking care of the orphans or those children abandoned by their impoverished parents. Therefore in an interview for "The Sun" on June 30, 1889, Mother Cabrini defined the main objective of her mission: “... to take Italian orphans away from the misery of the city and from the dangers threatening them in order to make them into decent people..." (Scaraffia 2017: 108). Cabrini’s first initiative in New York was to establish the House of the Holy Angels, a little orphanage at 43 East 59th Street where the nuns moved in on April 21, 1889 (Sullivan 1992: 91). Already in the year to follow, a much larger institution of that kind was inaugurated in West Park, located about a hundred miles from Manhattan, with a private garden and a farm, open to Italian children in need (Di Maria 1984: 129). In 1892 Mother Cabrini's New York empire expanded yet again. The nuns' first-hand experience as interpreters and intercultural mediators allowed them to notice the communication problems between Italian patients and American medical staff. They thus found it necessary to open their own clinic, the Columbus Hospital, accessible free-of-charge to Italian immigrants (Sullivan 1992: 167, 201). At the same time, an Italian Catholic school was established in Brooklyn (Scaraffia 2017: 103).

Although most of her initiatives remained linked to the realm of education, from the very outset Mother Cabrini wished them to have an impact on a much greater scale. In a letter to the Italian Commissioner General for Emigration, Leone Reynaudi, on July 20, 1907, she argued:

Yet, the influence that these schools exercise is not limited to the 5,000 children enrolled, but extends to the entire colony. The school itself is only the center around which other works of charity for the poor immigrants are gathered, like visits to the families, to public hospitals, to the prisons where the sisters bring material and moral aid to those poor unfortunates. [...] To the school there is united a church, which in various cities serves as a parish for the Italians. [...] Only a person who has lived far from their country, separated from the most precious domestic joys, lost sometimes among the huge plantations of extremely hot regions, or buried in the deep caverns of 
the mines, can value the sweetness that lies in the Sunday gathering for our workers who hurry to us in their best attire. There they hear a good word, which will animate them in their struggle for existence. [...] It has been estimated that in this way more than 30,000 Italians come into direct contact with the sisters during the year. It follows that the rapport between the sisters and the various colonies is most friendly; there is no public or domestic need in which the Italians do not have recourse to the sisters." (Sullivan 1992: 256)

She used a similar language when talking to the nuns of her congregation, thus outlining a general plan for global action, not only in terms of the groups of people to be affected but first and foremost the geographical scope of her projects:

What will soon be inaugurated in New York is a part of a much broader missionary endeavor, not only for the good of those children, but particularly for the families we will thus reach out to, ones that so badly need to be assisted. [...] Consider this: [there are] more than a hundred thousand Italians in New York alone, how many in all the different corners of the United States, how many throughout the world!" (Barbagallo 2013: 23-24)

Indeed Mother Cabrini's enterprise soon expanded beyond both New York City and State covering most of the U.S. territory and accompanying Italian immigrants in multiple local contexts. One strategy might seem highly surprising, that of promoting Italian community life in New Orleans as early as 1892 i.e. only several months after the infamous lynching of local Sicilians by an angry American mob (LaGumina 1999: 73). Just four months after she had opened an Italian school and a chapel in the city, Mother Cabrini decided to hold a public demonstration of Italian pride and solidarity within the local community, organizing an impressive and orderly religious procession carrying a large statue of the Holy Heart of Jesus among Catholic and patriotic hymns sung in Italian (Scaraffia 2017: 147). The case of New Orleans, at that time widely known as the Palermo of America, is just an example of how Mother Cabrini would use the genuine popular culture of the immigrants' area of origin in order to help shape a new identity of an Italian American "urban village" (Sullivan 1992: 165).

Since in the timespan of the following twenty years Cabrini-sponsored institutions multiplied throughout the United States, appearing in the states of New York, New Jersey, Pennsylvania, Louisiana, Mississippi, Illinois, Colorado, Washington and California, it is hardly surprising that Mother Cabrini has often been regarded as one of the great women travelers of her time (Barbagallo 2013: 14). "I am now in Chicago, on Monday I am going to New Orleans, then Los Angeles and Seattle, finally Denver. I will spend a week and a half in each of these places" - is a typical quote from Mother Cabrini's letters (Scaraffia 2017: 231). Having crisscrossed the North American continent a number of times, the foundress visited also Argentina, 
Panama, Nicaragua and Brazil, not forgetting to return frequently to Italy, Codogno and Rome in particular. According to her biographers' estimates she would cross the Atlantic at least twenty eight times, often scared to death by the dangers of such journeys "...thinking indeed she would die and [being] incapable even of saying «Jesus, mercy!»" (Serpentelli 1925: 24) It was also thanks to the larger-than-life activity of Mother Cabrini that at the time of her death in 1917 her charity empire consisted of sixty seven institutions located in eight countries outside the United States: Nicaragua and Panama, Argentina and Brazil, Italy and Spain, France and Britain (Sullivan 1992: 113).

Without questioning the widely propagated image of Mother Cabrini “...in a short time revealing exceptional qualities of foundress and manager..." (Scaraffia 2004: III), it seems nevertheless necessary to explore the fundraising strategies of the future saint or - in the words of a Catholic scholar - “...her important and positive relation to money..." (Barbagallo 2013:30). The first modest contributions made by other New York nuns only sufficed for the Cabrini sisters to barely subsist. In order to finance charitable works on a much greater scale another strategy was necessary, and the story reported below is a good illustration:

With no recommendation whatsoever, she would knock on the door of a rich Italian, Captain Pizzati, the owner of a merchant shipping company. The captain would ask her: "How can I help you, Reverend Mother?" Mother Cabrini would promptly reply: "It is me who want to help you". And since she knows he is childless she would offer him an opportunity to become a father. The captain would then say he is not yet ready to adopt a child. But Cabrini would ask: "A child? And what makes you think I want you to adopt a child?" "How many then?" - Captain Pizzati would ask back ironically. "Sixty for a start" - she would respond. And following his initial surprise she would convince him to finance an orphanage she is making plans for to house two hundred children, putting before his eyes the miserable fate of so many children living on the street as well as the heavy prejudice against all Italians, the good ones and the bad ones. She will thus obtain the money from the captain whom she will truly make a father of many." (Barbagallo 2013: 32)

Thus, first and foremost her strategy was based on inspiring a sense of solidarity among successful and wealthy Italian Americans towards the misery of their compatriots just arrived, the orphaned children in particular. With the same intentions Mother Cabrini frequently made requests for financial assistance to Italian government's Commissioner for Emigration or the Propaganda Fide. An image of Cabrini as a major point of reference to be reckoned with in all matters regarding assistance to Italian immigrants in America would gradually take hold even among cardinals (e.g. Leo XIII's Secretary of State, Mariano Rampolla), both in terms of the political aspect of nationality and the denominational aspect of their Catholic identity (Scaraffia 2017: 132). Among her powerful friends the name of Monsignor 
Giacomo della Chiesa must be mentioned, a Vatican prelate destined to become in 1914 Pope Benedict XV (Cummings 2018: 12). It also needs to be pointed out that as soon as it had been understood that Italian missionary sisters in America first needed to beg on the streets to survive, it discouraged potential competition from other Catholic institutions back in the mother country. Since no other helpers were thus available, numerous understaffed parishes in the centers of Italian immigration throughout the United States requested Cabrini's presence and assistance, which she often saw herself unable to provide to all those asking (Sullivan 1992: 102, 108).

However, Frances Cabrini's American adventure soon went beyond the centuries old Catholic charity tradition. Building upon the previous Irish immigrant experience, which had been transmitted to her by some novices already born U.S. citizens, she developed an interest in the American banking system and thanks to her many acquaintances among Irish Catholics she was able to obtain loans at reduced interest rates. Even more astonishing might seem her initiatives related to real estate investments not only as far as the congregation houses in America's largest cities are concerned but also when it comes to purchasing land in the Wild West, where she hoped to find gold and other precious mineral deposits (particularly impressive was the case of Mount Holy Cross in Colorado) (Scaraffia 2004: IV). Equally telling seems the fact that in 1900 Mother Cabrini applied for financial contributions - to no avail - from Andrew Carnegie, the iconic American self-made-man billionaire who had dedicated a part of his life to notable charity enterprises (Sullivan 1992: 133).

In the eyes of many American scholars, in the United States "the modest Lombardy teacher" had transformed into "a shrewd businesswoman" (Sullivan 1992: 135). Her pragmatic can-do approach originating from her solid Catholic faith worked surprisingly well into the context of the American Progressive Era, in full accordance with the motto to "think big". With no doubt it was America that offered Mother Cabrini the opportunities she could not dream of in the social and cultural reality of the Italy of her time. It thus seems right to take a closer look at how the future saint decided to match her two identities, Italian and American, in terms of her personal choice and that of the thousands of immigrants she had taken responsibility for.

\section{Identity dilemmas: 'A modern saint'}

The American "melting pot" reality forced Frances Cabrini to broaden her horizons, starting with a deeper reflection on the very question of Italianness. Just a few decades after Italy's formal unification in 1861, with a strong sense of traditional parochialism and a widespread Northern superiority complex against the Italian South unwilling to accept the liberal version of progress, also in the 
United States Italians were not regarded as a homogeneous nation but nothing short of two distinct "races": "North Italians" and "South Italians" (LaGumina 1999: 113). "Americans and uninitiated Danes such as Jacob Riis might call an area a Little Italy, but insiders knew any Little Italy could be divided into welldefined areas reserved for particular provinces and villages" (Brown 1995: 140). Cabrini's endeavor was thus, before anything else, to facilitate an intercultural encounter on American soil between the first 200-300 nuns coming almost solely from Lombardy (the North of Italy) and the immigrants, mostly Sicilians and other Southerners. Even the sisters would admit they needed to undergo “...a cultural conversion [...], to abandon prejudice (still existing today, imagine at the time)... [towards Southerners] ...considered ignorant people by Italians themselves..." (Barbagallo 2013: 28). At first one could perceive this situation as enormously paradoxical and delicate, if North Italian missionaries, according to both Italian and American criteria belonging to the "superior race", were expected to accommodate the Southern pariahs in the United States, often without even understanding the local dialects they spoke. Mother Cabrini aimed to reduce such barriers favoring the recruitment of novices descending from South Italian immigrants whose work largely contributed to the missionaries' success with the Italian American community (Sullivan 1992: 102).

What can be considered rather peculiar and surprising is Cabrini's approach to the question of the desired pattern of cultural identity among Italian immigrants in America. It must be admitted that the starting point and the fundamental objective of her New World mission had been to reject the concept of the United States as a "melting pot" according to which the new American immigrant citizens were expected to abandon the sense of belonging to their old European fatherland and to embrace exclusively their American dream, thus allowing the creation of a new uniform and egalitarian nation (Sullivan 1992: 159). In opposing such liberal projects, attractive especially to successful Italian Americans, as a Catholic conservative, Cabrini obviously insisted on the need to maintain one's own religious faith, but also the Italian national pride. Strangely enough, the Cabrini missionaries found themselves compelled to actually fabricate the latter ex nihilo in Italian immigrants, promoting the use of the Italian language instead of the numerous local dialects and a broader sense of Italianness in the place of strict parochialism. It was thus also thanks to Madre Cabrini's conscientious identity choice that many Italian Americans, who had lacked a strong, common national Italian identity back in the mother country, developed their awareness of Italianness only in America:

The foundress followed a specific strategy: the sisters would only speak Italian with the immigrants, in Italian would also be conducted all the religious services and the theatre shows, just like Italian-speaking was the staff of the hospitals and a part of school teaching. [...] Her approach was successful thanks to a massive campaign launched 
in a great number of schools strategically distributed throughout America and it thus overcame the previously dominant tendency to seek one's own individual integration into the American society." (Scaraffia 2017: 148)

However, it would be utterly wrong to perceive the Cabrini Institute as a fortress of Italian nationalism, totally opposed to immigrants' integration into the American society. In her letter to the Italian Commissioner General for Emigration on May 13, 1910 Mother Cabrini shed much light on her surprisingly practical and modern approach:

Regarding education, it is certain that it must be offered in the language of the country [i.e. in English] and that Italian has to be taught as a secondary subject. This is required by the needs of the children who have to earn bread in the land of adoption to which their parents have brought them. [...] We have children who habitually hear and speak $\mathrm{a}$ [n Italian] dialect. We are teaching Italian in practice more than in theory, at least in the first years of school, because experience has shown that a mixture of two languages, as far as the writing of the language is concerned, is detrimental to the progress of both languages. [...] When all is said and done, Honorable Commissioner, words are easy, and so are all exterior demonstrations of patriotism. It is easy to acclaim one's native land at banquets, in parades and with flag waving, but it is difficult to keep alive the love for Italy in the hearts of the youth in a hostile environment. [...] For me, to serve my country means to make her loved by the children entrusted to our care. It means to train them so they will not be ashamed to be Italians; it means to develop young people who will prove to their country of adoption that Italian immigration is not a dangerous element, but a desirable factor in the civilization and progress of a nation on whose shores Italy annually casts thousands of its emigrants." (Sullivan 1992: 260-261)

As can be inferred from the quoted passage, against the wishes of Italian authorities, Mother Cabrini favored with great zeal a vision of bilingual education, with a strong precedence of the English language before Italian in order to bring up "good Christians" and "good citizens" of the United States, conscientious of their own roots. In fact her educational program - defined as "education of the heart" - is often considered "...pedagogical reflection [...] ahead of its time, [...], personalized education" to be compared with the ideas of Maria Montessori (Barbagallo 2013: 7) or Don Giovanni Bosco's preventive system (Ragusa 2009: 27-31).

What needs to be highlighted is that in the above quoted letter from 1910, that is a year after she had obtained U.S. citizenship, Frances Cabrini still defined America as a "hostile environment". It is an important expression of her typical ambiguity with respect to her newly chosen mother country. At the first sight America seemed to her a tough reality, dominated by the spirit of anti-Catholicism and Italophobia. In fact, in June 1889 she wrote in a letter: "It is distressing to see such magnificent edifices dedicated to Protestant worship, Jewish and other sects! Nearby there are seven Protestant churches and a Jewish temple, all well-supported and exceedingly 
beautiful. I would so much like to have the wealth to buy all of them for our Holy Faith." (De Maria 1984: 122) On the other hand, she would learn to appreciate the ideals of equality, democracy and social progress, totally absent from early $20^{\text {th }}$ century Italy dominated by an elitist bourgeois anticlerical ruling class. Far as she remains from any ecumenical projects, rejecting to co-operate with Protestants, non-believers and freemasons, her institutions were open to non-Catholics. Her hospital's Jewish patients, in particular, at that time also viewed with contempt by U.S. Protestant high society, were happy to provide financial contributions to the Cabrini works (Sullivan 1992: 92). It was the freedom of action she was offered by the United States that would gradually win her over, especially when confronted with the anticlerical measures adopted by the Italian government of her time. Towards the end of her life one can trace in her letters some plans to move the whole activity of her Missionary Institute to America "... in case Italy should arrive at the final disgrace, $[\ldots]$ if for some reason they truly wanted to torment us in Italy." (Scaraffia 2017: 335)

It is in this context that one needs to interpret Frances Cabrini's most conspicuous identity choice i.e. to become U.S. citizen. Apart from securing for herself and her Institute a refuge from the increasing Italian anticlericalism, her decision must have been dictated by practical bureaucratic necessities, of utmost importance to anyone running a real estate empire throughout the country and by her desire to demonstrate with her own personal example the way she wished millions of Italian immigrants to follow through (Cummings 2018:7). Thus in 1909 in Seattle Mother Cabrini became American citizen, even though - in full accordance with the Italian American stereotype - she would never develop a good command of the English language (Sullivan 1992: 138). In one of her first letters from America she was right to have written: "I fear the day of judgment will come before I learn English" (Serpentelli 1925: 14).

However, if Mother Cabrini has been considered a "modern saint" of her time this is certainly not only because of her success in running the property of her Institute, her numerous voyages or her ability to propose an innovative strategy for the integration of Italian immigrants into the American society but because all this was achieved by a woman in the profoundly man-dominated society of the early $20^{\text {th }}$ century. This particular aspect of her enterprise has often been highlighted by Catholic gender scholars, especially in the United States (Cummings 2009: 5). It seems, indeed, evident that being a woman, a Catholic and an Italian, all three considered "inferior" categories, made Francesca Cabrini's social status exceptionally adverse in the American reality of her time. Of this she was totally aware when writing to her nuns: "Nothing in fact is difficult in this world, but to us, poor women, all seems difficult, all heavy and we are only good at talking as long as nothing happens..." or "...I need strong arguments against strong deceiving men." (Scaraffia 2017: 195) 
However, Mother Cabrini decided to challenge the stereotype of a childish and submissive woman adding to her religious project “... a strong emancipationist aspect [or that of] ...making women responsible and emancipated [...]. Suffice it to think [says Lucetta Scaraffia] that it was only in 1919 that Italian women were recognized the legal authority to run their own property [while] she and her sisters [in America] controlled substantial sums of money and decided about important investments trusting in their own business capabilities." (Scaraffia 2004: III) One can actually see through the Institute's financial documentation the great extent to which the foundress of the Missionaries of the Sacred Heart enjoyed an absolute economic autonomy, leaving a degree of freedom of action also to other nuns placed in charge of the local institutions, with their distinct backgrounds (Sullivan 1992: 125). The Cabrini sisters trespassed the borders of what was considered universally accepted woman behavior also in one more sense: "Her work was also extended to coal mines, prisons, cotton plantations, railway construction sites, all those places where she and her nuns went to help Italians" (Barbagallo 2013: 13), where - one must bear in mind - decent women normally never set foot. Therefore Catholic scholars argue that Mother Cabrini's experience demonstrates in fact how the nuns had within the Church much more space and opportunity to take a significant public social role than many feminists, including the Protestants of that time (Cummings 2009: 3).

Such was also the idea of Cabrini herself since in her letters from foreign countries she would often declare the Catholic religion as a supreme warrant of women's unmatched dignity viewed within a conservative perspective of the cult of the Holy Virgin:

The Indian woman, as in all those nations which have not received the light of faith, has to work while the man quietly smokes opium. [...] See how grateful we should be to Christianity, which has raised the dignity of woman, re-establishing her rights, unknown to the pagan nations. [...] But Mary appeared, this new Eve, true Mother of the Living, elected by God to be the Co-Redemptrix of the human race, and a new era arose for woman. She was no longer a slave, but equal to man; no longer a servant, but mistress within her domestic walls; no longer the object of disdain and contempt, but raised to the dignity of Mother and Educator, on whose knee generations are built up." (Serpentelli 1925: 256)

As a result, even though she might be seen as a Catholic feminist avant la lettre, Mother Cabrini rejected the suffragettes' struggle for voting rights and found no appreciation for the ideas spread by the feminists of her time e.g. by declining an invitation to take part in the First National Congress of Italian Women in 1908. It can be deduced that to her mind "...the real emancipated one was herself, who could do the same and better than men, but kept intact within her feminine sensibility to help the suffering, to intervene specifically to relieve not only the 
material difficulties but first and foremost the loneliness and the spiritual vacuum in those human beings left underprivileged by their lives" (Scaraffia 2004: III). The embarrassment that this "remarkable woman", as she was often defined by Americans, provoked in many men is confirmed by the fact the Italian ambassador to the United States called her "a great man" (Italian "un grande uomo"), while the notoriously anticlerical Minister Francesco Saverio Nitti considered her "a statesman" (Italian "uno statista") who would make a perfect minister of foreign affairs or commanding general of the army (Sullivan 1992: 36, 94, 145). In this way - as one biographer has put it - Mother Cabrini “...opened a new path of women's active piety shaping an original model of the relationship between the Catholic faith and modernity...", allowing nuns as women to live "... an experience ahead of their time [as well as] play a new and decisive role..." in the future fate of the Church in between their Italian and American identities united by the universal Catholic message (Scaraffia 2004: II).

\section{Conclusion: "The Immigrant of the Century"}

Mother Frances Xavier, defined by the Missionary Sisters of the Sacred Heart as "the noble heroine of charity", died in Chicago on December 22, 1917, at the age of 67. She had spent 28 years of her life in America. She undoubtedly died in odore sanctitatis since already during her lifetime, twelve years before her death, she had been proclaimed "a Catholic saint" by a New Orleans newspaper (Sullivan 1992: 145). The sisters of her Institute as well as the Catholic bishops of America put much pressure on the Roman Curia to see this prophecy come true as soon as possible. The beatification ceremony presided over by Pius XI and held in Rome on November 13, 1938 made a very positive impression on those U.S. prelates present. After their return to America many of them, including the Chicago cardinal, George Mundelein, praised Italy and the Mussolini regime with great enthusiasm. It needs to be stressed that the Fascist government, in power from 1922, had supported the work of the Cabrini sisters abroad, making their foundress post mortem an "ambassador of Italianness in the world" (D'Agostino 2004: 249, 256). Nevertheless fascists never managed to totally instrumentalize the cult of Francesca Cabrini and thus on July 7, 1946, in the midst of Italy's profound political transition from fascism to democracy, the new pope, Pius XII, canonized her as the first U.S. citizen to be proclaimed Catholic saint. On September 17, 1950 she was also declared the patroness of emigrants. An impressive statue of the new saint had been placed in St. Peter's Basilica already in 1947 (De Luca 2000: XXI).

Simultaneously her legend grew also in the United States. Mother Cabrini was buried in New York, in the very place where her American adventure had started, later to become a shrine in her honor. Her life and work was commemorated at 
The Ellis Island National Museum of Immigration, on the pedestal of the Statue of Liberty and on the bronze door of St. Patrick's Cathedral in New York (Danilov 2005: 69-70). The peak of the Cabrini public legend came when on October 30, 1952 she was declared "the Italian Immigrant of the Century" by the American Committee for Italian Migration among words of admiration sent for the occasion by the cardinal of New York, Francis Spellman, President Harry Truman and Italian Prime Minister Alcide De Gasperi as well as American (e.g. "The New York Times"), Italian American (e.g. "Il Progresso italo-americano") and Catholic ("L'Osservatore Romano") press. In his message Harry Truman remarked that "for countless immigrants [...] it was Mother Cabrini's generous arms that reached out to help them and her indomitable spirit that gave them strength to build new lives in this country" (Sullivan 1992: 2). In his foreword to the most recent Cabrini biography Pope Francis has pointed out that Francesca Cabrini is therefore "still showing us the ways to be traversed while facing the historic phenomenon of migrations with charity and justice" (Scaraffia 2017: 15).

This short analysis of the cult of Francesca Cabrini allows one to claim that post mortem she has become - according to St. Paul's famous motto - "everything to everybody" - "... a woman of very traditional faith, at the same time in love with modernity, living a life of humility and obedience, yet capable of investing impressive capitals in giant enterprises trusting her own forces, [thus] a new saint, modern, and at the same time, a traditional mystic." (Scaraffia 2004: IV) An independent woman admired by popes, statesmen and businessmen, a thinker offering fresh and up-to-date ideas on integrating immigrants into a new society, “... reconciling liberty, personal initiative and courage typical of a modern individual with religious roots she thought defined our identity" (Scaraffia 2004: IV). Even when abandoning the hagiographic tones dominant in research produced by the Cabrini sisters or other emotionally engaged Catholic authors, one needs to admit along with many American scholars that "... without Frances Cabrini to have been an Italian immigrant in the United States between 1889 and 1917 would have been a much harder lot." (Sullivan 1992: 248)

\section{References}

American Heritage Dictionary (AHD): https://ahdictionary.com/ (Accessed: 30 July 2017).

Barbagallo M. (2013). "Buoni Cristiani" e "Buoni Cittadini": l'opera, la missione educativa e la pedagogia di Santa Francesca Cabrini. Codogno: Missionarie del Sacro Cuore di Gesù.

Brown M. E. (1995). Churches, Communities, and Children: Italian Immigrants in the Archdiocese of New York, 1880-1945. New York: Center for Migration Studies.

Cashmore E. (2004). Encyclopedia of Race and Ethnic Studies. London-New York: Routledge.

Cipolla I. (2012 [1926]). Tra un'onda e l'altra. Viaggi di Santa Francesca Saverio Cabrini. Roma: Centro Cabriniano Online: http://msccabrini.it/index.php/it/scritti-93050/9-i-viaggi?start=20 (accessed: 21 April 2017). 
Cummings K. (2009). New Women of the Old Faith: Gender and American Catholicism in the Progressive Era. Chapel Hill: University of North Carolina Press.

Cummings K. (2018). Frances Cabrini, American Exceptionalism, and Returning to Rome. [in:] The Catholic Historical Review, Vol. 104 No. 1, pp. 1-23.

Curtis S. (2010). Civilizing Habits: Women Missionaries and the Revival of French Empire. Oxford: Oxford University Press.

Curtis S. (2016). The Double Invisibility of Missionary Sisters. [in:] Journal of Women's History, Vol. 28 No. 4, pp. 134-143.

D’Agostino P. (2004). Rome in America. Transnational Catholic Ideology from the Risorgimento to Fascism. Chapel Hill: University of North Carolina Press.

Danilov V. (2005). Women and Museums: A Comprehensive Guide. New York: Altamira Press.

De Luca G. (2000). Madre Cabrini: la santa degli emigrati. Roma: Edizioni di Storia e Letteratura.

De Maria S. (1984 [1927]). Mother Frances Xavier Cabrini. Chicago: Missionary Sisters of the Sacred Heart of Jesus.

Dhamoon R. K. (2016). Feminisms, in: G. Waylen, K. Celis, J. Kantola, S. L. Weldon (eds.), The Oxford Handbook of Gender and Politics, Oxford: Oxford University Press, pp. 88-110.

Eriksen T. H. (2010). Ethnicity, Race and Nation, in: M. Guibernau \& J. Rex (eds.), The Ethnicity Reader. Nationalism, Multiculturalism \& Migration, Cambridge: Polity Press: pp. 46-53.

Fisher J. T. (2008). Communion of Immigrants: A History of Catholics in America. Oxford: OUP.

Gillis C. (1999). Roman Catholicism in America. New York: Columbia University Press.

Glazer N. \& Moynihan D. (1975). Ethnicity. Theory and Practice. Cambridge: Harvard University Press.

LaGumina S. (1999). WOP! A Documentary History of Anti-Italian Discrimination. Toronto: Guernica.

LaGumina S. (2000). The Italian American Experience: An Encyclopedia. New York: Routledge.

Merriam-Webster Dictionary (MWD): https://www.merriam-webster.com/ (accessed: 30 July 2017).

McGreevy J. (2003). Catholicism and American Freedom. A History. New York: Norton\&Company.

Piller I. (2011). Intercultural Communication: A Critical Introduction. Edinburgh, Edinburgh University Press.

Podemski P. (2016). Traduttore... salvatore: lesperienza degli immigrati italo-americani a Ellis Island nei ricordi autobiografici di Fiorello La Guardia, in: P. Kuon (ed), Narrarsi per ritrovarsi. Pratiche autobiografiche nelle esperienze di migrazione, esilio, deportazione, Firenze: Franco Cesati Editore, pp. 29-38.

Ragusa A. (2009). Il metodo don Bosco tra pedagogia e storia. Milano: Lampi di stampa.

Scaraffia L. (2004). Francesca Cabrini. Milan: Paoline Online: http://msccabrini.it/index.php/it/ scritti- 93049/13-testimonianze (accessed: 21 April 2017).

Scaraffia L. (2017). Tra terra e cielo. Vita di Francesca Cabrini. Venezia: Marsilio.

Serpentelli G. (1925). The Travels of Mother Frances Xavier Cabrini. Exeter: Streatham Hall.

Shaw R. (2016). Catholics in America. Religious Identity and Assimilation. San Francisco: Ignatius Press.

Sullivan M. L. (1992). Mother Cabrini: Italian Immigrant of the Century. New York: Center for Migration Studies.

Tucci S. (2015). The Italian Americans. DVD. Arlington: PBS-The National Italian American Foundation.

Żelazny W. (2004). Etniczność. Ład-konflikt-sprawiedliwość. Poznań: Wydawnictwo Poznańskie. 